\title{
Keragaman Karakter Morfologi, Komponen Hasil, dan Hasil Plasma Nutfah Kedelai (Glycine max L.)
}

\section{Diversity of Morphological Characteristics, Crop's Yield Components, and Germplasm Yield of Soybean (Glycine max L.)}

\author{
Priskilla Purnaning Putri, Adisyahputra, Asadi \\ Corresponding author; email: priskilla_purput@yahoo.com
}

\begin{abstract}
Soybean (Glycine max L.) is annual crop that have high morphologies and yield components diversity. The research was conducted at the first season of 2011, the objective of the research were to find morphological, yield, and yield component of Soybean germplasm (Glicine max L.). The research was carried out at experimental station BB-BIOGEN Citayam, Depok, and laboratory of Gene Bank BB-BIOGEN. The experiment used randomized block design with 100 different accessions and three replications for each accession. Based on the observation, the morphological characters have many visual forms. They are as follows: growth percentage in which 19.33 - 99\%; growth types were determinate and indeterminate, the leave form was triangle to sharp; purple and white flowers; yellow and black seeds color. The range of values for each characteristic component are as follows: plant height 29,23-104,25 cm; number of pods per plant was 23,6 - 99,82; flowering time $33-47$ days after planting; 100 seed weight 5,98 - 20,77 gram; maturing time 75 - 96,67 days after planting; root nodule's weight $0,004-$ 0,109 gram; seed's weight 3,15-11,45 gram/plant. Among the accessions, the highest yield was shown by B 4323 (643,27 gram/3,6 m2). Significant correlation was shown between soybean's yield components and yield which were plant's height, growth percentage, numbers of main stem's node, numbers of pods, seeds weight for each plant and root nodule's weight. 100 seeds weight showed significant negative correlation with soybean components.
\end{abstract}

Key words: germplasm, morphological characteristics, soybean, yield components.

\section{Pendahuluan}

Wilayah Indonesia yang membentang luas dengan kondisi geografi dan ekologi yang bervariasi telah menciptakan keanekaragaman plasma nutfah yang sangat tinggi. Plasma nutfah merupakan bahan genetik yang memiliki nilai guna, baik secara nyata maupun yang masih berupa potensi. Tingginya tingkat keanekaragaman plasma nutfah tersebut telah memberikan peluang untuk mendapatkan manfaat yang tinggi pula. Dengan tingginya keanekaragaman plasma nutfah, maka terbuka peluang yang besar pula bagi upaya mencari dan memanfaatkan sumber-sumber gen penting yang ada untuk program pemuliaan. Oleh karena itu, tingginya keanekaragaman plasma nutfah memiliki aspek yang sangat penting untuk dipertahankan (DEPTAN, 2004).

Tanaman kedelai (Glicine max L.) merupakan tanaman komoditas pangan nasional prioritas ketiga setelah padi dan jagung. Kedelai sebagai sumber utama protein nabati merupakan bahan baku makanan yang bergizi. Kontribusi kedelai sangat dominan dalam menu pangan terutama dikonsumsi dalam bentuk tempe, tahu, kecap, dan susu. Protein nabati dalam konsumsi pangan di Indonesia masih menunjukkan proporsi yang tinggi. Sumber protein nabati dalam menu pangan masih didominasi oleh kacang-kacangan terutama kedelai (Wirnas, 2005).

Setiap tahun komsumsi kedelai dalam negeri terus meningkat yang ditunjukkan dengan meningkat jumlah impor kedelai sejalan dengan pertambahan jumlah penduduk. Kebutuhan kedelai tahun 2004 mencapai 2,02 juta ton, sedangkan produksinya baru 0,72 juta ton, sehingga diperlukan impor 1,30 juta ton (DEPTAN, 2010). Untuk mengurangi impor kedelai, dilakukan upaya peningkatan produksi dengan cara intensifikasi dan perluasan areal tanam. Penggunaan 
varietas unggul merupakan salah satu komponen identifikasi untuk meningkatkan produksi kedelai. Dalam penelitian varietas unggul, sumber gen sebagai tetua persilangan diperoleh dari evaluasi dan karakterisasi plasma nutfah kedelai. BB-BIOGEN memiliki mandat dalam pengelolaan plasma nutfah pertanian. Koleksi plasma nutfah kedelai pada tahun 2004, 2005, 2006, 2007, dan 2008 berturut-turut adalah 771, 771, 741, 765, dan 767 nomor aksesi (Harnoto et al., 2008; Tasma et al., 2009). Agar plasma nutfah kedelai tersebut dapat dimanfaatkan sebagai sumber tetua persilangan dalam memperbaiki varietas, maka perlu dilakukan pelestarian (rejuvenasi) dan karakterisasi sifat morfologi dan komponen hasilnya.

\section{Metode Penelitian}

Penelitian ini telah dilaksanakan pada bulan Oktober 2010 hingga Februari 2011, bertempat di Kebun Percobaan BB-BIOGEN Citayam, Depok, dan Bank Gen BB-BIOGEN, Bogor, Jawa Barat.

Metode yang digunakan dalam penelitian ini yaitu eksperimen dengan teknik observasi lapang dan pengamatan langsung dengan keragaman morfologi berdasarkan parameter: (1) tipe daun, (2) tipe pertumbuhan tanaman, (3) warna hipokotil, (4) warna bunga, dan (5) warna biji. Keragaman komponen hasil berdasarkan parameter: (1) tinggi tanaman, (2) jumlah buku per tanaman, (3) jumlah polong per tanaman, (4) umur berbunga 50\%, (5) bobot 100 biji, (6) umur masak, (7) bobot bintil akar, (8) bobot biji per tanaman, dan (9) hasil biji per petak 3,6 $\mathrm{m}^{2}$. Percobaan disusun dalam Rancangan Acak Kelompok (RAK), dengan 3 ulangan, sebagai perlakuan adalah 100 nomor aksesi.

Untuk memilih aksesi yang dapat dijadikan kandidat unggul dalam komponen hasil dan hasil dilakukan dilakukan secara deskriptif. Individu-individu yang memiliki keunggulan pada setiap parameter komponen hasil dan hasil yang dipilih menjadi unggulan.

Alat-alat yang digunakan dalam penelitian ini adalah tambang, meteran, ajir, tugal, kacip, timbangan digital chyo jp2-3000, straples dan isinya, kantung kertas, karung, dan tali rafia. Bahan-bahan yang digunakan adalah 100 aksesi kedelai, pupuk NPK Ponska, pestisida Marshal, pestisida Decis, pestisida Uracon, pestisida Dursban dan pestisida Baycarb. berikut:

Persiapan dan prosedur penelitian dilakukan mengikuti langkah-langkah sebagai

Persiapan Lahan, mempersiapkan lahan untuk menanam dengan mengolah tanah dan memberikan pupuk. Luas petak percobaan $3 \mathrm{~m}$ x 1,2 $\mathrm{m}$ ( 3 baris, panjang baris $3 \mathrm{~m}$ ), jarak tanam $40 \mathrm{~cm} \times 15 \mathrm{~cm}$. Benih yang telah disiapkan ditanam sebanyak 2-3 benih pada setiap lubang. Penanaman dilakukan sebanyak 3 kali ulangan untuk setiap aksesi kedelai.

Penjarangan, pemupukan dan pengendalian hama, pada 7 hari setelah tanam (hst) dilakukan penjarangan dengan menyisakan dua tanaman yang ukurannya seragam. Tanaman dipelihara, dirawat serta di beri pupuk. Pupuk diberikan seminggu setelah tanam. Pengontrolan hama tanaman menggunakan pestisida Marshal pada benih sebelum ditanam, dan pestisida Decis, Dursban, Uracon dan Baycarb, diberikan mulai umur 2 minggu, selang 1-2 minggu menjelang panen polong muda.

Pengamatan dan Panen, pengamatan komponen hasil kedelai dilakukan meliputi persentase tanaman yang tumbuh, umur berbunga 50\%, jumlah buku/tanaman, jumlah polong/ tanaman, bobot 100 biji, umur masak, bobot bintil akar, kandungan air biji saat panen, bobot biji/tanaman, dan hasil biji/petak. Panen kedelai dilakukan setelah daun gugur dan warna polong kuning kecoklatan. Setelah panen, berangkasan dikeringkan kemudian dilakukan perontokkan biji. Biji atau benih setiap aksesi dibersihkan, lalu dikeringkan sampai kadar air 8-9\%.

Data yang diperoleh antara lain:

1. Menghitung persentase tanaman yang tumbuh pada $7 \mathrm{hst}$.

2. Morfologi tanaman kedelai:

a. Menentukan warna hipokotil, yang terdiri dari warna putih atau ungu dan dapat dilihat pada 5-7 hst. 
b. Menentukan tipe pertumbuhan batang, yang terdiri dari tipe determinit, indeterminit, dan semi determinit. Tipe determinit yaitu dengan melihat pertumbuhan vegetatif tunas terminal terhenti ketika terjadi pembungaan, indeterminit dengan melihatnya dari tunas terminal melanjutkan fase vegetatif selama pertumbuhan, dan menurut Wawan (2006), semi determinit dapat dilihat dari tipe batang mirip keduanya, pada beberapa kasus varietas hasil persilangan.

c. Menentukan tipe atau bentuk daun, yang terdiri dari lanset, segitiga, oval meruncing atau oval membulat.

d. Menentukan warna bunga kedelai, yang terdiri dari warna ungu atau putih.

e. Menentukan warna biji, yang terdiri dari warna kuning, hijau, hitam, atau coklat.

3. Komponen hasil kedelai:

a. Mengukur tinggi tanaman dari buku batang pertama hingga ujung batang utama.

b. Menghitung jumlah buku batang utama.

c. Menghitung umur berbunga 50\% tanaman yang telah berbunga.

d. Menghitung jumlah polong isi setiap sampel tanaman.

e. Menimbang bobot 100 biji kedelai pada setiap aksesi.

f. Menghitung umur masak dengan melihat $80 \%$ warna polong kecoklatan atau daun rontok dalam setiap aksesi.

g. Menimbang bobot bintil akar.

h. Menimbang bobot biji setiap sampel tanaman.

i. Menghitung jumlah cabang pada batang utama.

j. Menimbang bobot hasil biji per petak seluas 3,6 $\mathrm{m} 2$.

Data-data tersebut akan ditabulasi ke dalam suatu tabel untuk selanjutnya dilakukan pengolahan data dan dianalisis menggunakan pearson product momment antara faktor $\mathrm{x}_{\mathrm{i}}$ sebagai komponen hasil dan faktor y sebagai hasil biji per petak. Untuk memilih aksesi yang dapat dijadikan kandidat unggul dalam komponen hasil dan hasil dilakukan dilakukan analisis deskriptif .

\section{Hasil dan Pembahasan}

Berdasarkan hasil penelitian yang telah dilakukan, diperoleh data persentase tumbuh, karakter morfologi, komponen hasil dan hasil plasma nutfah kedelai (Glycine max L.) sebagai berikut:

1. Persentase Tumbuh Tanaman Kedelai

Hasil uji viabilitas benih yang dilakukan sebelum penanaman, menunjukan persentase yang tinggi (100\%), yaitu pada aksesi B 609, B 1350, B 1586, B 1671, B 3607, B 3616, B 3628, B 3630, B 3633, B 3681, B 3762, B 3840, B 3897, B 3916, B 4042, B 4157, B 4224, B 4327, dan B 3890. Sedangkan persentase tumbuh tertinggi pada aksesi B 906, B 1550, dan B 3897 sebanyak 99,00\%. Hasil uji viabilitas terendah $25 \%$ dan $31 \%$, terdapat pada aksesi B 3774 dan B 3778, sedangkan persentase tumbuh terendah pada aksesi B 3774, yaitu 19,33\%. Hal ini disebabkan karena proses penurunan mutu secara berangsur-angsur dan kumulatif serta tidak dapat balik (irreversible) akibat perubahan fisiologis yang disebabkan oleh faktor dalam. Proses penuaan atau mundurnya vigor secara fisiologis ditandai dengan penurunan daya berkecambah, peningkatan jumlah kecambah abnormal, penurunan pemunculan kecambah di lapangan (field emergence), terhambatnya pertumbuhan dan perkembangan tanaman, meningkatnya kepekaan terhadap lingkungan yang ekstrim yang akhirnya dapat menurunkan produksi tanaman (Copeland \& Donald, 1985).

2. Keragaman Karakter Morfologi Tanaman Kedelai

a. Warna hipokotil tanaman kedelai diamati pada hari ke 5-7 memiliki dua variasi warna. Terdapat 16 aksesi dengan hipokotil berwarna hijau, dan sebanyak 84 aksesi berwarna ungu.

b. Tipe pertumbuhan batang tanaman kedelai terlihat 2 tipe, yaitu tipe determinit dan 
indeterminit. Hasil pengamatan diketahui bahwa sebanyak 44 aksesi memiliki tipe pertumbuhan batang determinit dan sebanyak 56 aksesi tipe indeterminit.

c. Bentuk daun tanaman kedelai memiliki 3 macam, yaitu lanset (namun tidak ditemukan), segitiga terdapat 38 aksesi, dan meruncing terdapat 62 aksesi.

d. Warna bunga tanaman kedelai memiliki dua macam, yaitu bunga berwarna putih sebanyak 16 aksesi, dan bunga berwarna ungu sebanyak 84 aksesi.

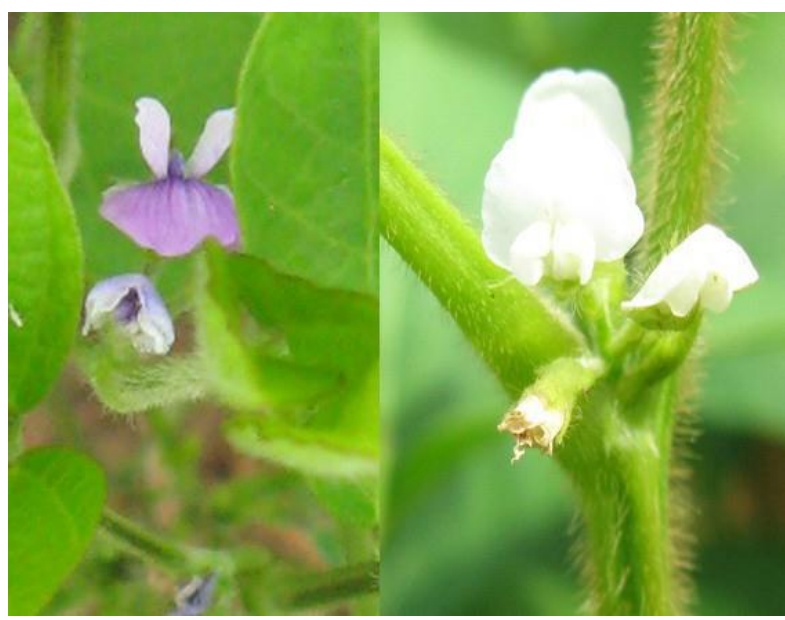

a

b

Gambar 3. Ragam Warna Bunga Kedelai: (a) ungu; (b) putih.

e. Warna biji kedelai diketahui memiliki macam warna, yaitu kuning, hijau, hitam dan coklat. Terdapat pula warna kombinasi (campuran) yaitu kuning hijau dan hijau kuning. Hasil pengamatan diperoleh warna biji kedelai kuning sebanyak 54 aksesi, hijau sebanyak 1 aksesi, hitam sebanyak 27 aksesi, dan coklat sebanyak 1 aksesi. Sedangkan warna kombinasi kuning kehijauan (memiliki perbandingan 65:35 hingga 85:15) sebanyak 10 aksesi, dan hijau kekuningan (memiliki perbandingan 65:35 hingga 80:20) sebanyak 7 aksesi.

a

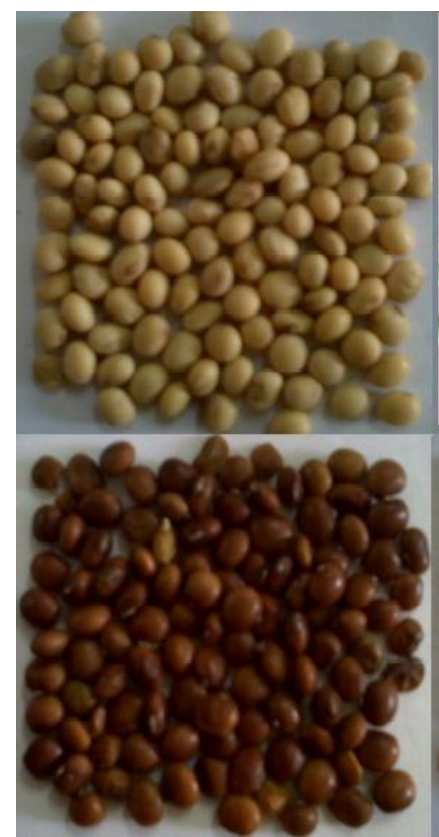

d b

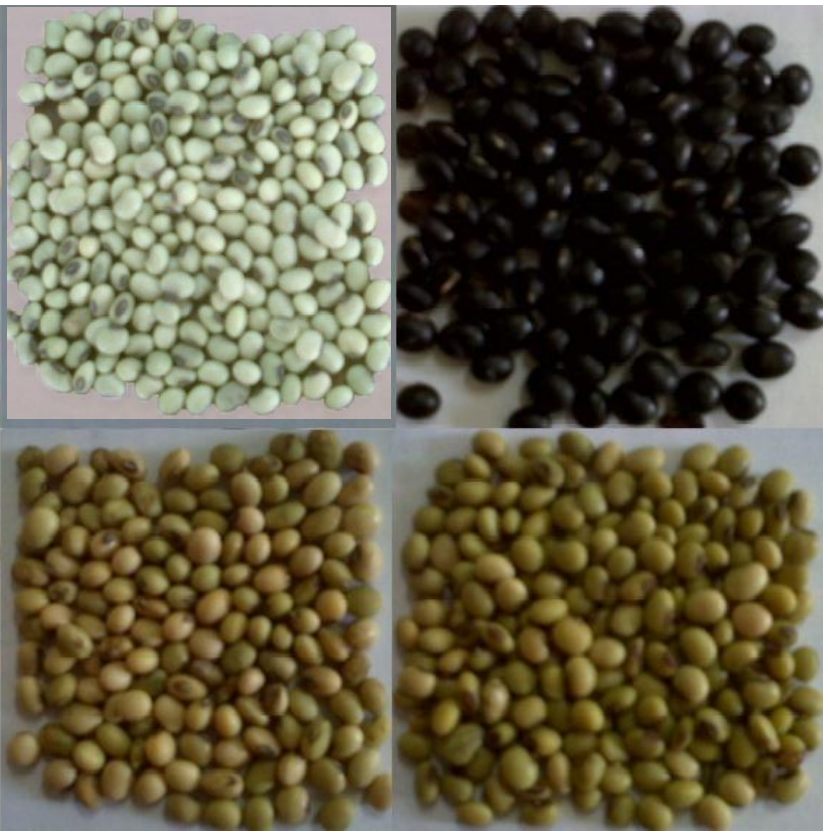

e $\mathbf{f}$

Gambar 4. Ragam Warna Biji Kedelai: Atas: (a) kuning; (b) hijau; (c) hitam; Bawah: (d) coklat; (e) kuning kehijauan; (f) hijau kekuningan. 
3. Keragaman Komponen Hasil dan Korelasi terhadap Hasil Tanaman Kedelai

a. Keragaman Karakter Komponen Hasil dan Hasil Plasma Nutfah Kedelai.

Karakter komponen hasil dapat dilihat pada tabel 1.

Tabel 1. Karakter Komponen Hasil Plasma Nutfah Kedelai.

\begin{tabular}{|c|c|c|}
\hline Karakter Komponen Hasil & Jumlah Aksesi & Contoh Aksesi \\
\hline \multicolumn{3}{|l|}{ Tinggi tanaman $(\mathrm{cm}):$} \\
\hline$<40 \quad$ (pendek) & 1 & \\
\hline 40-60 (sedang) & 21 & \\
\hline $60-80$ (tinggi) & 52 & \\
\hline$>80 \quad$ (sangat tinggi) & 26 & В 4405, В 3696, В 3678, В 3556, В 3702 \\
\hline \multicolumn{3}{|l|}{ Jumlah buku batang utama: } \\
\hline$<10$ & - & \\
\hline 10 sampai 20 & 96 & \\
\hline$>20$ & 4 & В 4391, В 4405, В 4224, В 3678, В 3906 \\
\hline \multicolumn{3}{|l|}{ Umur berbunga (HST) } \\
\hline$<35$ & 9 & Grobogan, B 4232, B 4300, B 4357, B 4215 \\
\hline $35-40$ & 34 & \\
\hline$>40$ & 57 & \\
\hline \multicolumn{3}{|l|}{ Jumlah polong/tanaman: } \\
\hline$<25 \quad$ (sedikit) & 3 & \\
\hline 25-50 (sedang) & 46 & \\
\hline 51-75 (agak banyak) & 44 & \\
\hline$>75 \quad$ (banyak) & 7 & B 4391, В 4405, B 3678, В 3906, В 4224 \\
\hline \multicolumn{3}{|l|}{ Jumlah cabang/tanaman: } \\
\hline$<1$ & 1 & \\
\hline 1 sampai 3 & 67 & \\
\hline$>3$ & 32 & В 4391, В 609, B4397, В 1430, В 618 \\
\hline \multicolumn{3}{|l|}{ Bobot 100 biji (gram): } \\
\hline$<10$ & 84 & \\
\hline 10 sampai 20 & 15 & В 4222, В 4232, В 4216, В 4215, В 3801 \\
\hline$>20$ & 1 & Grobogan \\
\hline \multicolumn{3}{|l|}{ Umur masak (HST): } \\
\hline$<80 \quad$ (genjah) & 16 & В 609, В 1396, В 618, В 4397, В 3623 \\
\hline $80-90$ (sedang) & 61 & \\
\hline$>90 \quad$ (dalam) & 23 & \\
\hline \multicolumn{3}{|l|}{ Bobot bintil akar (gram/tanaman): } \\
\hline$<0,005$ & 1 & \\
\hline $0.005-0,01$ & 21 & \\
\hline $0,011-0,1$ & 77 & В 618, В 1550, В 3073, В 3286 \\
\hline$>0,1$ & 1 & B 902 \\
\hline \multicolumn{3}{|l|}{ Bobot biji/tanaman (gram/tanaman): } \\
\hline$<5$ & 6 & \\
\hline 5 sampai 10 & 86 & \\
\hline$>10$ & 8 & В 2981, В 3469, В 3906, В 4212, В 4405 \\
\hline \multicolumn{3}{|c|}{ Bobot biji per petak 3,6 m2 (gram/3,6 m2): } \\
\hline$<100$ & - & \\
\hline $100-300$ & 14 & \\
\hline $301-500$ & 77 & \\
\hline$>500$ & 9 & B 4323, Wilis, B 4042, B 906 \\
\hline
\end{tabular}


Pada bobot 100 biji tertinggi, pada varietas Grobogan (20,77 gram), memiliki bobot bintil akar 0,004 gram yang tergolong rendah, dan bobot biji per tanaman hanya 6,73 gram. Varietas Grobogan memiliki bobot 100 biji tertinggi, karena biji kedelai varietas Grobogan tergolong dalam biji besar, sehingga memiliki bobot biji yang besar pula. Begitu pula dengan bobot 100 biji terendah yaitu 5,98 gram (B 3623) namun memiliki bobot bintil akar cukup tinggi, yaitu 0,011 gram/tanaman dan bobot per tanaman 6,26 gram.

Benih baru yang diperoleh dari penelitian ini adalah 120,06 - 643,27 gram. Terlihat bahwa tidak ada aksesi yang menghasilkan biji dibawah 100 gram, sehingga dapat diartikan bahwa perolehan hasil biji kedelai cukup baik. Jika terdapat hasil biji dibawah 100 gram, maka sangat perlu dilakukan rejuvenasi kembali, agar benih yang ada dalam bank gen tetap tersedia dan tidak punah (hilang).

Dalam menentukan aksesi yang dapat dijadikan kandidat unggul berdasarkan karakter komponen hasil dan hasil ditentukan berdasarkan kriteria nilai $\mathrm{x}=\mu+0,5 \sigma$. Aksesi - aksesi yang terseleksi adalah aksesi menunjukan karakter komponen hasil dan hasil terbaik pada setiap parameter yang diukur, berupa tinggi tanaman, umur berbunga, jumlah buku batang utama, jumlah polong, bobot 100 biji, umur masak, bobot biji per tanaman, bobot bintil akar, jumlah cabang serta hasil biji per petak.

Berdasarkan perhitungan, aksesi yang dapat dijadikan kandidat unggul berdasarkan komponen hasil dan hasil adalah 6 aksesi, yaitu B 3556 (tinggi tanaman, umur berbunga, jumlah buku, jumlah polong, umur masak, bobot bintil akar, dan jumlah cabang); B 3678 (tinggi tanaman, umur berbunga, jumlah buku, jumlah polong, umur masak, bobot biiji per tanaman, dan jumlah cabang); B 3696 (tinggi tanaman, umur berbunga, jumlah buku, jumlah polong, umur masak, bobot biiji per tanaman, dan jumlah cabang); B 4224 (tinggi tanaman, umur berbunga, jumlah buku, jumlah polong, umur masak, jumlah cabang, dan hasil biji per petak); B 4391 (tinggi tanaman, umur berbunga, jumlah buku, jumlah polong, umur masak, bobot biji per tanaman, dan jumlah cabang); dan B 4405 (tinggi tanaman, umur berbunga, jumlah buku, jumlah polong, umur masak, bobot biiji per tanaman, dan jumlah cabang); yang masing-masing memiliki 7 parameter terbaik.
b. Korelasi Komponen Hasil dan Hasil Plasma Nutfah Kedelai
Berdasarkan pengamatan dan perhitungan yang dilakukan, terdapat korelasi atau
hubungan antar parameter dan hubungan parameter dengan hasil kedelai (tabel 2).

Tabel 2. Matriks koefisien korelasi karakter komponen hasil plasma nutfah kedelai (Glycine max L.).

\begin{tabular}{|c|c|c|c|c|c|c|c|c|c|c|}
\hline Variabel & $\mathrm{X1}$ & $\mathrm{X} 2$ & X3 & $\mathrm{X4}$ & X5 & X6 & $\mathrm{X} 7$ & $\mathrm{X8}$ & X9 & $\mathrm{X10}(\mathrm{Y})$ \\
\hline $\mathrm{X} 1$ & 1 & $0,616^{* *}$ & $0,846^{* *}$ & $0,668^{* *}$ & $-0,449 * *$ & $0,557 * *$ & $0,386^{* *}$ & $-0,070$ & 0,067 & $0,355^{* * *}$ \\
\hline $\mathrm{X} 2$ & & 1 & $0,652^{* *}$ & $0,621 * *$ & $-0,603 * *$ & $0,543 * *$ & 0,176 & $-0,135$ & 0,056 & 0,134 \\
\hline X3 & & & 1 & $0,753 * *$ & $-0,481 * *$ & $0,620 * *$ & $0,542 * *$ & $-0,169$ & 0,144 & $0,298 * *$ \\
\hline $\mathrm{X} 4$ & & & & 1 & $-0,540 * *$ & $0,500^{* *}$ & $0,639 * *$ & 0,002 & $0,474 * *$ & $0,222 *$ \\
\hline X5 & & & & & 1 & $-0,049$ & $-0,033$ & $-0,123$ & $-0,364 * *$ & $-0,388^{* *}$ \\
\hline X6 & & & & & & 1 & $0,414 * *$ & $-0,214^{*}$ & $-0,084$ & $-0,046$ \\
\hline $\mathrm{X} 7$ & & & & & & & 1 & 0,006 & 0,183 & $0,235^{*}$ \\
\hline X8 & & & & & & & & 1 & $0,250 *$ & $0,207 *$ \\
\hline X9 & & & & & & & & & 1 & 0,065 \\
\hline $\mathrm{X} 10(\mathrm{Y})$ & & & & & & & & & & 1 \\
\hline
\end{tabular}

Keterangan: *) berbeda nyata; **) berbeda sangat nyata

$X_{1}=$ tinggi tanaman; $X_{2}=$ umur berbunga; $X_{3}=$ jumlah buku batang utama;

$X_{4}=$ jumlah polong; $X_{5}=$ bobot 100 biji; $X_{6}=$ umur masak; $X_{7}=$ bobot biji per tanaman;

$\mathrm{X}_{8}=$ bobot bintil akar; $\mathrm{X}_{9}=$ jumlah cabang; dan $\mathrm{X}_{10}(\mathrm{Y})=$ hasil biji per petak. 
Karakter komponen hasil seperti tinggi tanaman, jumlah buku per tanaman, jumlah polong per tanaman, umur berbunga 50\%, bobot 100 biji, umur masak, bobot bintil akar, dan bobot biji per tanaman merupakan komponen produksi (variabel x) yang mempengaruhi hasil (variabel y). Karakter jumlah polong per tanaman dapat digunakan untuk kriteria seleksi dalam mendapatkan genotipe kedelai yang berdaya hasil tinggi. (Asadi, 2004).

Dari hasil penelitian ini diketahui bahwa karakter tinggi tanaman berkorelasi positif sangat nyata dengan umur berbunga, jumlah buku pada batang utama, jumlah polong, umur masak, dan bobot biji per tanaman. Hal ini menunjukan terdapat kecenderungan berubah secara bersama dalam arah yang sama atau cenderung menurun atau meningkat secara bersama. Hal ini menunjukan bahwa semakin meningkat umur berbunga, jumlah buku pada batang utama, jumlah polong, umur masak, dan bobot biji per tanaman, maka tinggi tanaman kedelai akan meningkat.

Karakter tinggi tanaman, umur berbunga, jumlah buku pada batang utama, jumlah polong, dan jumlah cabang pula berkorelasi negatif sangat nyata dengan bobot per 100 biji. Hal ini berarti semakin meningkat bobot per 100 biji akan menurunkan tinggi tanaman, umur berbunga, jumlah buku pada batang utama, jumlah polong, dan jumlah cabang.

Hasil penelitian ini yaitu hasil biji per petak dengan luas 3,6 $\mathrm{m} 2$ berkorelasi positif sangat nyata dengan tinggi tanaman, persentasi tumbuh dan jumlah buku batang utama sehingga dapat diasumsikan bahwa semakin tinggi tanaman, persentasi tumbuh dan jumlah buku batang utama, maka hasil biji per petak akan semakin meningkat. Namun, terlihat pula karakter bobot 100 biji berkorelasi negatif sangat nyata terhadap hasil biji per petak, sehingga dapat diartikan bahwa semakin meningkat hasil biji per petak, maka akan menurunkan bobot 100 biji.

Komponen hasil jumlah polong isi, bobot per tanaman dan bobot bintil akar juga berkorelasi nyata dengan hasil biji per petak. Hal ini menunjukan bahwa semakin tinggi jumlah polong isi, bobot per tanaman dan bobot bintil akar, maka semakin meningkat pula hasil biji per petaknya. Semakin tinggi jumlah polong isi dan bobot per tanaman, secara logika, sudah pasti pula biji yang dihasilkan akan meningkat pula. Bobot bintil akar meningkat dan berperan dalam fiksasi kebutuhan nitrogen dari dalam tanah yang dibutuhkan oleh tanaman semakin tinggi pula, sehingga pertumbuhan tanaman baik dan menghasilkan biji yang meningkat pula.

\section{Kesimpulan}

Kesimpulan penelitian "Keragaman Karakter Morfologi, komponen Hasil, dan Hasil Plasma Nutfah Kedelai (Glycine max L.)" adalah:

1. Karakter morfologi tanaman kedelai (Glycine max L.) memiliki banyak bentuk visual tanaman, mulai dari warna hipokotil (ungu), tipe pertumbuhan batang (indeterminit), tipe atau bentuk daun (meruncing), warna bunga (ungu), dan warna biji kedelai (kuning) yang beragam.

2. Karakter komponen hasil tanaman diantara aksesi plasma nutfah kedelai memiliki ragam yang tinggi, yaitu tinggi tanaman $(29,23-104,25 \mathrm{~cm})$, jumlah buku per tanaman $(10,25-$ 21,19 buku), jumlah polong (23,60-99,82 polong/tanaman), umur berbunga 50\% (33-47 HST), bobot 100 biji (5,98-20,77 gram), umur masak (75-96,67 HST), bobot bintil akar (0,004-0,109 gram/tanaman), dan bobot biji (3,15-11,47 gram/tanaman).

3. Terdapat korelasi atau hubungan signifikan antara komponen hasil dengan hasil plasma nutfah kedelai, yaitu pada tinggi tanaman $(0,355)$ dan jumlah buku batang utama $(0,298)$, jumlah polong isi $(0,222)$, bobot per tanaman $(0,235)$, dan bobot bintil akar $(0,207)$ serta bobot 100 biji $(-0,388)$, namun berkorelasi negatif.

\section{Daftar Pustaka}

Asadi, Soemartono, M. Woerjono dan H. Jumanto. (2004). Keefektifan Metode Seleksi Modifikasi Bulk dan Pedigri untuk Karakter Agronomi dan Ketahanan Terhadap Virus Kerdil (SSV) Galur-Galur F7 Kedelai. Zuriat, 15 (1): 64-76. 
Copeland. L.O. dan M.B. Mc. Donald. (1985). Principles of Seed Science and Technology. New York: Burgess Publishing Company.

DEPTAN (Departemen Pertanian). (2004). Katalog Data Paspor Plasma Nutfah Tanaman Pangan. Bogor: BB-BIOGEN.

DEPTAN (Departemen Pertanian). (2010). Tren Produksi dan Produktivitas 5 Komoditas Utama Pertanian. Pusat Data dan Informasi Pertanian.

Harnoto, Asadi, Yunus, Iswari S. Dewi, Budihardjo Soegiarto, Minantyorini, dan Karden Mulya. (2008). Laporan Tahun 2007 BB-BIOGEN. Badan Litbang. Departemen Pertanian.

Wawan, Aep. (2006). Budidaya Tanaman Kedelai (Glycine max (L.) Merill). Skripsi. Bandung: Universitas Padjadjaran.

Wirnas, Desta. (2005). Analisis Kuantitatif Dan Molekular Dalam Rangka Mempercepat Perakitan Varietas Baru Kedelai Toleran Terhadap Intensitas Cahaya Rendah. Makalah Pribadi Falsafah Sains (PPS 702). Bogor: Sekolah Pasca Sarjana IPB. 